\title{
UPAYA PENINGKATAN MUTU PENDIDIKAN AGAMA ISLAM: PROBLEMATIKA DAN SOLUSI
}

\author{
Amatul Jadidah \\ Institut Agama Islam Al-Qolam Malang, Indonesia \\ Email: amatuljadidah@alqolam.ac.id
}

\begin{tabular}{l|l|l} 
Received: April 2021 & Accepted: Juli 2021 & Published: Juli 2021
\end{tabular}

\begin{abstract}
Education is a means in building the character of the nation in building a highly civilized society, where Islamic Religious Education is an important part.. For this reason, efforts to improve the quality of religious education are important to overcome the problems. The purpose of this study was to find out the problems of implementing Islamic religious education and how to improve the quality of education at Madrasah Ibtidaiyah Al Hikmah in Wringinanom, Poncokusumo District, Malang Regency. In this study, the researcher uses a qualitative type, which emphasizes natural descriptions, and data collection or phenomena collection is carried out from reasonable circumstances. Therefore, researchers are directly involved in the field. From the results of the study, there were several problems found, namely: low cognitive abilities of students; commitment, quality and competence of educators that need to be improved; The lack of understanding of educators about the 2013 curriculum; lack of cooperation between a small number of parents and educators and limited infrastructure. Efforts to overcome these problems, madrasas are carried out in several ways: for students, providing educational sanctions, forming student group work, discussions between students in class, and providing additional hours. For educators, participating in seminars and workshops. For the curriculum, by increasing the socialization of the implementation of the 2013 curriculum. For management, it seeks to increase the involvement between the guardians of students and the community in an effort to improve quality, through meetings. For facilities and infrastructure, the school will seek the realization of facilities and infrastructure that do not yet exist, such as libraries.
\end{abstract}

Kata Kunci: educational problems, Islamic Religious Education, Madrasah

\begin{abstract}
Abstrak: Pendidikan merupakan sarana dalam membangun watak bangsa dalam membangun masyarakat yang berperadaban tinggi, di mana Pendidikan Agama Islam menjadi bagian penting. Untuk itu, upaya peningkatan mutu pendidikan Agama menjadi penting untuk diatasi problematikanya. Tujuan penelitian ini adalah untuk mengetahui Problematika Pelaksanaan Pendidikan Agama Islam dan bagaimana upaya meningkatkan Mutu Pendidikan di Madrasah Ibtidaiyah Al Hikmah di Wringinanom Kecamatan Poncokusumo Kabupaten Malang. Dalam penelitian ini, peneliti menggunakan jenis kualitatif, yang menekankan pada deskripsi secara alami, dan pengambilan data atau penjaringan fenomena dilakukan dari keadaan yang sewajarnya. Oleh karena itu, peneliti terlibat langsung di lapangan. Dari hasil penelitian, ada beberapa problem yang ditemukan yaitu: rendahnya kemampuan kognitif peserta didik; komitmen, kualitas dan kompetensi pendidik yang perlu ditingkatkan; Minimnya pemahaman pendidik tentang kurikulum 2013; kurang terjalinnya kerjasama sebagian kecil orang tua dengan pendidik dan Keterbatasan Sarana prasarana. Upaya mengatasi problematika tersebut, dilakukan madrasah dengan beberapa cara: untuk peserta didik, memberikan sanksi yang bersifat mendidik, membentuk kerja kelompok peserta didik, diskusi antar peserta didik di dalam kelas, dan memberikan jam tambahan. Untuk pendidik, diikutsertakan dalam acara seminar dan workshop. Untuk kurikulum, dengan meningkatkan sosialisasi penerapan kurikulum 2013. Untuk manajemen, berupaya meningkatkan keterlibatan antara wali siswa dan juga masyarakat dalam upaya peningkatan mutu, melalui pertemuan. Untuk sarana dan prasarana, sekolah mengupayakan terwujudnya sarana \& prasarana yang belum ada, seperti perpustakaan.
\end{abstract}

Kata Kunci: problematika pendidikan, Pendidikan Agama Islam, Madrasah 


\section{A. Pendahuluan}

Dunia pendidikan saat dihadapkan pada berbagai masalah yang sangat kompleks yang membutuhkan penanganan cepat agar tidak ketinggalan zaman. Sebab, pendidikan merupakan hal yang sangat penting bagi setiap manusia dalam menghadapi setiap permasalahan hidup yang cenderung hedonis atau materialis. Kini, semakin banyak orang yang memilih pendidikan non agama yang menjanjikan pekerjaan lebih mudah daripada pendidikan agama. ${ }^{1}$ Di sisi lain, mutu pendidikan di Indonesia masih belum menggembirakan untuk menghadapi tantangan yang sangat berat di masa depan. Untuk itu, dalam masa reformasi saat ini, pendidikan memerlukan perhatian yang sangat serius. Dibutuhkan perbaikan dan peningkatan dalam segala sektor dalam pendidikan yang meliputi guru, murid juga sarana dan prasarana seperti Kurikulum yang memadai. ${ }^{2}$ Dan Sekolah merupakan organisasi pendidikan yang berhubungan langsung dengan pihak-pihak yang berkepentingan (stakeholder) sehingga sekolah lebih mengetahui kekuatan, kelemahan, peluang maupun ancaman yang dihadapinya.

Menurut Mukhtar Bukhori, ${ }^{3}$ praktik pendidikan Islam di Indonesia pada umumnya dibagi menjadi empat bagian: 1) Pendidikan pondok pesantren, yaitu pendidikan yang diselenggarakan secara tradisional. 2) Pendidikan madrasah merupakan pendidikan yang diselenggarakan di lembaga-lembaga pendidikan model barat yang menggunakan metode-metode pengajaran klasik dan berusaha menanamkan nilai-nilai Islami sebagai landasan hidup dalam diri setiap peserta didik. 3) Pendidikan umum yang bernafaskan Islam, 4) Pendidikan Islam yang diselengarakan di lembaga pendidikan umum sebagai bagian dari mata pelajaran. Dari ulasan diatas menunjukkan bahwa pendidikan merupakan tolak ukur dalam membangun masyarakat yang berperadaban tinggi. Suatu bangsa akan maju, dinamis, harmonis dan berkualitas bilamana pendidikan yang ada juga berkualitas.

Amin Abdullah ${ }^{4}$ menyoroti kegiatan Pendidikan Agama ${ }^{5}$ yang selama ini berlangsung di sekolah, antara lain: 1) Pendidikan agama selama ini lebih banyak terkonsentrasi pada persoalanpersoalan teoritis keagamaan yang bersifat kognitif semata; 2) Pendidikan agama kurang perhatian terhadap persoalan bagaimana mengubah pengetahuan yang kognitif menjadi "makna" dan nilai yang ada; 3) Isu kenakalan remaja, perkelahian antar pelajar, tindak kekerasan, premanisme, white

${ }^{1}$ Arief Furchan, Transformasi pendidikan Islam di Indonesia: anatomi keberadaan madrasah dan PTAI (Yogyakarta: Gama Media, 2004), 129.

2 Muhaimin, Arah Baru Pengembangan Pendidikan Islam: Pemberdayaan, Pengembangan, Kurikulum hingga Redefinisi Islamiah Pengetahuan (Bandung: Nuansa Cendekia, 2003), 148.

${ }^{3}$ Dalam Muhaimin, 13.

4 Dalam Muhaimin, Sutiah, dan Nur Ali, Paradigma Pendidikan Islam: Upaya Mengefektifkan Pendidikan Agama Islam di Sekolah, 5 ed. (Bandung: PT Remaja Rosdakarya, 2012), 90.

${ }^{5}$ Dalam UUSPN No.2/1989, pasal 28 ayat 1 ditegaskan untuk dapat diangkat sebagai tenaga pengajar, tenaga pendidik yang bersangkutan harus beriman dan bertaqwa terhadap Tuhan Yang Maha Esa, berwawasan Pancasila dan Undang Undang dasar 1945 serta memiliki kualifikasi sebagai tenaga pengajar. 
collar crime; 3) Metodologi pendidikan agama tidak kunjung berubah antara pra dan post era modernitas; 4) Pendidikan agama lebih banyak menitikberatkan pada aspek korespondensi, tekstual yang lebih menekankan hafalan teks-teks keagamaan yang sudah ada; 5) Sistem evaluasi, bentuk soal-soal ujian agama Islam menunjukkan prioritas utama pada kognitif dan jarang pertanyaan tersebut mempunyai bobot muatan "nilai" dan "makna" spiritual keagamaan yang fungsional dalam kehidupan sehari-hari.

Padahal, pendidikan Agama memberikan sumbangan yang besar terhadap kemajuan suatu bangsa dan merupakan wahana dalam menerjemahkan pesan-pesan konstitusi serta merupakan sarana dalam membangun watak bangsa. Masyarakat yang cerdas akan memberikan nuansa kehidupan cerdas pula, dan secara progresif akan membentuk kemandirian pada masyarakat itu sendiri. ${ }^{6}$ Tantangan dalam pendidikan agama Islam merupakan bagian dari tantangan dunia pendidikan di Indonesia pada umumnya, terutama dalam meningkatkan sumber daya manusia yaitu: Era kompetitif dunia kerja, Kualitas pendidikan, Kemajuan teknologi informasi, dalam hal metodologi, kualitas pendidikan, dan kenyataan empiris perkembangan masyarakat yang masih banyak tertinggal. ${ }^{7}$

Berdasarkan latar belakang problematika pendidikan yang dikemukakan para ahli, terdapat urgensi untuk mengungkap bagaimana kondisi riil permasalahan yang dihadapi lembaga pendidikan Islam (LPI) dalam upaya peningkatan mutu pendidikan Agama Islam dan bagaimana solusinya. Salah satu LPI yang menghadapi problematika tersebut adalah Madrasah Ibtidaiyah Al Hikmah Wringinanom Kecamatan Poncokusumo Kabupaten Malang. MI ini merupakan salah satu LPI juga mempuyai tanggung jawab dalam rangka mewujudkan cita-cita pendidikan, sudah tentu menghadapi beberapa problem yang dapat menghambat pelaksanaan pendidikan, khususnya pelaksanaan pendidikan agama Islam. Dengan berpijak pada fokus penelitian maka tujuan yang ingin dicapai dalam penelitian ini adalah: Untuk mendeskripsikan problematika yang dihadapi dalam proses pelaksanaan peningkatan mutu Pendidikan Agama Islam dan upayanya dalam mengatasi problema pendidikan Agama Islam tersebut.

\section{B. Kajian Literatur}

\section{Pengertian Pendidikan Agama Islam}

Pengertian pendidikan berasal dari bahasa Yunani yaitu: "paedagogie" yang berarti bimbingan yang diberikan kepada anak didik. Istilah ini diterjemahkan dalam bahasa Inggris dengan kata "Education". Kata pendidikan diistilahkan dalam bahasa arab dengan kalimat tarbiyah,

\footnotetext{
${ }^{6}$ Endang Mulyasa, Manajemen Berbasis Sekolah Konsep Strategi dan Implikasi (Bandung: PT. Remaja Rosdakarya, 2012), 4.

7 Muhaimin, Arah Baru Pengembangan Pendidikan Islam: Pemberdayaan, Pengembangan, Kurikulum hingga Redefinisi Islamiah Pengetahuan, 92.
} 
taklim dan takdib. ${ }^{8}$ Dalam Undang-undang Nomor 2 tahun 1989 tentang sistem pendidikan Nasional, pasal 1 menjelaskan, bahwa "Pendidikan" adalah usaha sadar untuk menyiapkan peserta didik melalui kegiatan bimbingan, pengajaran, dan pelatihan bagi peranannya di masa yang akan datang. ${ }^{9}$ Sedang Dalam GBPP mata pelajaran pendidikan Islam kurikulum tahun 1994 dinyatakan bahwa yang dimaksud dengan pendidikan Agama Islam ditambah dengan: "memperhatikan tuntutan untuk menghormati agama lain dalam hubungan kerukunan antar umat beragama dalam masyarakat untuk mewujudkan persatuan nasional".10

Menurut Abdur Rahman Nahlawi pendidikan Islam adalah "Pengaturan pribadi dan masyarakat sehingga dapat memeluk Islam secara logis dan keseluruhan baik dalam kehidupan individu maupun kolektif.11 Sedangkan Marimba mengartikan Pendidikan Islam adalah bimbingan jasmani dan rohani berdasarkan hukum-hukum agama Islam menuju terbentuknya kepribadian utama menurut ukuran nilai-nilai Islam. ${ }^{12}$ Dalam pengertian tersebut dapat ditemukan beberapa hal yang perlu diperhatikan dalam kegiatan pendidikan agama Islam yaitu:

a. Pendidikan agama Islam sebagai usaha sadar, pembimbingan, pengajaran dan pelatihan yang dilakukan secara berencana dan sadar akan tujuan yang ingin dicapai.

b. Peserta didik yang hendak disiapkan untuk mencapai tujuan dalam arti ada yang dibimbing, diajari dan atau dilatih dalam meningkatkan keyakinan, pemahaman, penghayatan dan pengamalan terhadap ajaran agama Islam.

c. Pendidik atau guru pendidikan agama Islam yang melakukan kegiatan bimbingan, pengajaran, dan atau latihan secara sadar terhadap peserta didiknya untuk mencapai tujuan tertentu.

Kegiatan pendidikan agama Islam diarahkan untuk meningkatkan keyakinan, pemahaman, penghayatan, pengamalan ajaran islam dari peserta didik yang disamping untuk membentuk kesalehan untuk kualitas pribadi juga sekaligus membentuk kesalehan sosial.

\section{Dasar Pelaksanaan Pendidikan Agama Islam}

Dasar pendidikan Islam identik dengan ajaran Islam itu sendiri, yakni keduanya berasal dari sumber Al-Qur'an dan Hadist. yang merupakan sumber kebenaran dalam Islam, yang tidak dapat diragukan lagi. menjadi undang-undang dan memberi petunjuk bagi manusia., dan menjadi sarana

\footnotetext{
${ }^{8}$ Ahmad Tafsir, Ilmu pendidikan dalam perspektif Islam (Bandung: Remaja Rosdakarya, 1994), 24.

9 Presiden Republik Indonesia, Undang-Undang Republik Indonesia Nomor 20 Tahun 2003 Tentang Sistem Pendidikan Nasional (Jakarta, 2003), 3.

10 Muhaimin, Arah Baru Pengembangan Pendidikan Islam: Pemberdayaan, Pengembangan, Kurikulum hingga Redefinisi Islamiah Pengetahuan, 75.

11 Sanaki Hujair, Paradigma pendidikan Islam; membangun masyarakat madani (Yogyakarta: Safarina Insani Prees, 2003), 15.

12 Ramayulis, Ilmu Pendidikan Islam (Jakarta: Kalam Mulia, t.t.), 3.
} 
pendekatan diri dan mendapatkan pahala bagi pembacanya. ${ }^{13}$ Pendidikan agama Islam mempunyai peranan penting dalam mewarnai kehidupan manusia, baik dalam kehidupan keluarga, maupun dalam kehidupan bangsa dan negara ${ }^{14}$

Adapun mengenai dasar pelaksanaan pendidikan agama di Indonesia memiliki status yang cukup kuat. Dasar tersebut dapat ditinjau dari beberapa segi yaitu:

Tabel 1. Dasar Pelaksanaan Pendidikan Agama Islam

\begin{tabular}{|c|c|}
\hline Dasar & Keterangan \\
\hline Yuridis & $\begin{array}{l}\text { a. Ideal: ketetapan MPR No. II/MPR/1978 tentang P415 } \\
\text { b. Struktural/Konstitusional: dasar yang berasal dari UUD } 1945 \text { dalam bab XI } \\
\text { pasal } 29 \text { ayat } 1 \text { dan } 2 . \\
\text { c. Operasional: UUD } 1945 \text { dalam bab XI pasal } 29 \text { ayat } 1 \text { dan } 2 . \\
\text { d. Tap MPR Nomor XXVII/1966 tentang "Agama Pendidikan dan Kebudayaan" } \\
\text { e. Keputusan menteri agama No.52 tahun } 1971 \text { tentang Kurikulum madrasah. } \\
\text { f. Keppres Nomor } 34 \text { tahun } 1973 \text { dan Inpres Nomor } 15 \text { tahun } 1974 .\end{array}$ \\
\hline Operasional & $\begin{array}{l}\text { Undang-Undang No } 2 \text { tahun } 1989 \text { tentang sistem pendidikan nasional pada Bab IX } \\
\text { pasal pasal } 39 \text { ayat } 2 \text { dinyatakan bahwa "Isi kurikulum setiap jenis, jalur dan } \\
\text { jenjang pendidikan wajib memuat a) Pendidikan Pancasila, b) Pendidikan agama, } \\
\text { c) Pendidikan Kewarganegaraan".16 }\end{array}$ \\
\hline Religious & $\begin{array}{l}\text { a. Melaksanakan pendidikan agama adalah merupakan perintah dari Tuhan dan } \\
\text { hukumnya wajib merupakan ibadah kepadaNya ( Qs. An Nahl: 125) } \\
\text { b. "Tiap tiap anak dilahirkan dilahirkan diatas fitrah maka ibu bapaknyalah yang } \\
\text { mendidiknya menjadi orang yang beragama yahudi, nasrani dan majusi "(HR. } \\
\text { Bukhari Muslim). }{ }^{17}\end{array}$ \\
\hline Psikologi & $\begin{array}{l}\text { Semua manusia dalam hidupnya didunia ini, selalu membutuhkan adanya } \\
\text { pegangan hidup yang disebut agama, orang-orang muslim diperlukan adanya } \\
\text { pendidikan agama Islam, agar dapat mengarahkan fitrah mereka tersebut ke arah } \\
\text { yang benar, sehingga mereka akan dapat mengabdi dan beribadah sesuai dengan } \\
\text { ajaran Islam. Tanpa adanya pendidikan agama dari satu generasi ke generasi } \\
\text { berikutnya maka akan semakin jauh dari agama yang benar. }\end{array}$ \\
\hline
\end{tabular}

${ }^{13}$ Abuddin Nata, Paradigma pendidikan Islam (Jakarta: Gramedia Widiasarana Indonesia bekerjasama dengan IAIN Syarif Hidayatullah, 2001), 293.

${ }_{14}$ Abu Ahmadi dan Nur Uhbiyati, Ilmu Pendidikan (Jakarta: Rineka Cipta, 2003), 66. Nasional.

15 Indonesia, Undang-Undang Republik Indonesia Nomor 20 Tahun 2003 Tentang Sistem Pendidikan

16 Mahmud Yunus, “Metodik Khusus Pendidikan Agama,” Jakarta: Hidakarya Agung, 1983, 19.

${ }^{17}$ Nata, Paradigma pendidikan Islam, 292. 


\section{Tujuan Pendidikan Agama Islam}

Ibnu Miskawaih menyatakan bahwa tujuan pendidikan Islam adalah terwujudnya sikap batin yang mampu mendorong atau memotivasi secara spontan untuk melahirkan perbuatan yang bernilai baik. Sementara Al-Qabisi menyatakan bahwa tujuan pendidikan Islam adalah menumbuh kembangkan pribadi anak sesuai dengan nilai-nilai Islam yang benar. Demikian Ibnu Sina menyatakan bahwa tujuan pendidikan agama Islam adalah mengembangkan seluruh potensi yang dimiliki seseorang ke arah perkembangan yang sempurna, yaitu perkembangan fisik, intelektual dan budi pekerti.18 Munir Mursi menjabarkan tujuan pendidikan Islam menjadi sebagai berikut: Bahagia di dunia dan juga di akhirat, menghambakan diri kepada Allah SWT, memperkuat ikatan keislaman dan melayani kepentingan masyarakat Islam, Akhlak mulia ${ }^{19}$ yang meliputi Aspekaspek kepribadian, berupa kejasman, kejiwaan, kerohanian. ${ }^{20}$ Secara umum, Pendidikan Agama Islam bertujuan untuk meningkatkan keimanan, pemahaman, penghayatan, dan pengamalan peserta didik tentang agama Islam, sehingga menjadi insan yang muslim, beriman dan bertakwa kepada Allah SWT serta berakhlak mulia dalam kehidupan pribadi, bermasyarakat, berbangsa dan bernegara. ${ }^{21}$

\section{Problematika Dalam Pelaksanaan Pendidikan Agama Islam}

\section{a. Problem Anak Didik Dalam Pendidikan Agama Islam}

Selama ini memang dirasakan bahwa proses pendidikan Islam terkesan menganut asas subject matter oriented yang membebani peserta didik dengan informasi-informasi yang kognitif dan motorik yang kurang relevan dengan kebutuhan dan tingkat perkembangan psikologi peserta didik. ${ }^{22}$ Adapun problem-problem yang terdapat pada anak didik antara lain: Problem kemampuan ekonomi keluarga, intelegensi, bakat dan minat, perkembangan dan pertumbuhan, kepribadian, sikap, sifat, kerajinan dan ketekunan, pergaulan, kesehatan. ${ }^{23}$

\section{b. Problem Pendidik Dalam Pendidikan Agama Islam}

Pendidik dalam pendidikan Agama Islam dapat diistilahkan dengan (muallim, murabbi, muaddib) yang kesemuanya dituntut untuk komitmen continuous improvement, yakni selalu berusaha memperbaiki dan memperbaharui model model yang sesuai dengan tuntutan zamannya,

18 Makmur Haris Fathoni, Pendidikan Islam dan Krisis Moralisme Masyarakat Modern (Yogyakarta: IRCiSoD, 2008), 12.

19 Tafsir, Ilmu pendidikan dalam perspektif Islam, 46.

${ }^{20}$ Hamdani Ihsan dan Fuad Ihsan, Filsafat Pendidikan Islam (Bandung: Pustaka Setia, 1998), 68-69.

${ }^{21}$ Muhaimin, Arah Baru Pengembangan Pendidikan Islam: Pemberdayaan, Pengembangan, Kurikulum hingga Redefinisi Islamiah Pengetahuan, 78.

${ }^{22}$ Hujair, Paradigma pendidikan Islam; membangun masyarakat madani, 244.

${ }^{23}$ Ramayulis, Ilmu Pendidikan Islam, 106. 
yang dilandasi oleh kesadaran tinggi bahwa tugas mendidik adalah tugas menyiapkan generasi penerus yang akan hidup pada masa zamannya. Gambaran tentang hakikat pendidik dalam Islam adalah orang orang yang bertanggung jawab terhadap perkembangan peserta didik dengan mengupayakan seluruh potensi peserta didik, baik afektif, kognitif dan psikomotorik.

Gary A Davis \& Margaret A. Thomas, ${ }^{24}$ mengemukakan tentang ciri pendidik yang efektif meliputi empat kelompok: Pertama, memiliki pengetahuan yang terkait dengan iklim belajar di kelas, Kedua, kemampuan yang terkait dengan strategi manajemen pembelajaran, yang terdiri: Ketiga, memiliki kemampuan yang terkait dengan pemberian umpan balik (feed back) dan penguatan (reinforcement), Keempat, memiliki kemampuan yang terkait dengan peningkatan dengan peningkatan diri.

\section{c. Problem Kurikulum Dalam Pendidikan Agama Islam}

Dalam Bahasa Arab kurikulum diistilahkan manhaj yang berarti jalan terang yang dilalui oleh manusia pada berbagai kehidupan. Sedangkan arti manhaj/kurikulum dalam pendidikan Islam sebagaimana yang terdapat dalam kamus At-Tarbiyah adalah seperangkat perencanaan dan media yang dijadikan acuan oleh lembaga pendidikan dalam mewujudkan tujuan-tujuan pendidikan. ${ }^{25}$

Menurut istilah Paulo Freire, implementasi kurikulum untuk mewujudkan tujuan pendidikan masih bermodel analog dengan banking concept. Yaitu pendidik selalu melakukan deposito berbagai macam informasi ke bank peserta didik tanpa harus tahu untuk apa informasi itu bagi kehidupan mereka. Akibat dari model pengajaran seperti ini, peserta didik memiliki pengetahuan, tetapi peserta didik kering dan tidak memiliki sikap, minat dan motivasi dan kreatifitas untuk mengembangkan diri atas dasar pengetahuan yang dimiliki. ${ }^{26}$ Oleh karena itu program kurikulum harus diorientasikan dan disesuaikan dengan kebutuhan masa kini dan masa yang akan datang, agar mencegah terjadinya calon-calon penganggur intelektual.

Amin Abdullah menanggapi masalah kurikulum Pendidikan Islam lebih banyak terkonsentrasi pada persoalan-persoalan teoritis keagamaan yang bersifat kognitif semata-mata. kurang concern menjadi "makna", lebih menitik beratkan pada aspek korespondensi tekstual, Sistem evaluasi, ${ }^{27}$ menekankan ortodoksi dalam mata pelajaran agama yang diidentikkan dengan keimanan, dan bukan ortopraksis yaitu bagaimana mewujudkan iman dalam tindakan nyata operasional.

${ }^{24}$ Suyanto dan Djihad Hisyam, Refleksi dan reformasi pendidikan di Indonesia memasuki Milenium III (Jakarta: Adicita, 2000), 29.

${ }^{25}$ Rosmiaty Azis, "Implementasi pengembangan kurikulum," Jurnal Inspiratif Pendidikan 7, no. 1 (2018): 44-50.

${ }^{26}$ Hujair, Paradigma pendidikan Islam; membangun masyarakat madani, 220.

${ }^{27}$ Hujair, 264. 


\section{d. Problem Manajemen Dalam Pendidikan Agama Islam}

Manajemen merupakan terjemahan dari kata management yang berarti pengelolaan, ketatalaksanaan. ${ }^{28}$ Dalam pengelolaan sistem pendidikan di Indonesia, "posisi pendidikan Islam masih dalam posisi marginal, Pembiayaan pendidikan Islam tidak diambil dari anggaran negara bidang pendidikan, tetapi dari anggaran bidang agama, sehingga anggaran pembiayaan pemerintah untuk pendidikan Islam jauh lebih kecil dibandingkan untuk pendidikan umum. Melihat kenyataan ini, maka reformasi manajemen pendidikan Islam menjadi suatu keharusan. ${ }^{29}$

Dengan langkah-langkah berusaha pembenahan dan peningkatan profesionalisme penyelenggaraan pendidikan dan Penerapan manajemen berbasis sekolah perlu disesuaikan dengan kebutuhan dan minat peserta didik, pendidik, serta kebutuhan masyarakat setempat. Sehingga akan mampu menjawab berbagai tantangan dan dapat memberdayakan pendidikan Islam di masa depan.

\section{e. Problem lingkungan, Sarana dan Prasarana Dalam Pendidikan Agama Islam}

Lingkungan adalah segala sesuatu yang tampak yang terdapat dalam alam kehidupan yang senantiasa berkembang, Lingkungan akan dapat menimbulkan pengaruh positif dan negatif terhadap pertumbuhan jiwa, dalam sikap maupun perasaan keagamaan. Seperti Suasana keluarga, Lingkungan masyarakat, pemahaman orang tua akan arti nilai-nilai agama Islam. bila lingkungan tersebut baik maka akan tumbuh perkembangan dan pembelajaran yang baik, sebaliknya bila buruk maka hasilnya pun akan buruk.

Yang dimaksud dengan prasarana pendidikan adalah fasilitas yang secara tidak langsung menunjang jalannya proses pendidikan atau pengajaran. ${ }^{30}$ Gagne mendefinisikan sarana pendidikan sebagai alat fisik yang dapat menyajikan pesan yang dapat merangsang peserta didik untuk belajar. ${ }^{31}$ Yusuf Hadi Miarso ${ }^{32}$ menyatakan sarana pendidikan Islam mempuyai nilai-nilai praktis yang berupa kemampuan atau kelebihan antara lain: Membuat konsep konkrit, Membawa obyek yang mudah, Menampilkan objek besar, Menampilkan objek yang dapat diamati, Mengamati gerakan, Memungkinkan keseragaman persepsi, membangkitkan motivasi belajar, Menyajikan informasi belajar secara konsisten. Dengan demikian apabila pendidikan Islam memanfaatkan dan menggunakan sarana pendidikan, maka peserta didik akan memiliki pemahaman yang bagus tentang materi yang diperoleh, dan juga diharapkan akan memiliki moral yang baik.

\footnotetext{
2003), 118.

31 Gagne RM, "The Condition of Learning and Theory of Intructions," Orlando: Rineheart and Winston, 1985, 167.

32 Ramayulis, Ilmu Pendidikan Islam, 190.
}

${ }^{28}$ Eddy Soetrisno, Kamus Populer Bahasa Indonesia (Ladang Pustaka, 2008).

${ }^{29}$ Hujair, Paradigma pendidikan Islam; membangun masyarakat madani, 164.

30 Djumhur Muhammad Surya, Bimbingan dan Penyuluhan di Sekolah Jilid 3 (Bandung: Erlangga, 


\section{Metode Penelitian}

Dalam penelitian ini, peneliti menggunakan jenis kualitatif, yaitu pelaksanaan penelitian ini memang terjadi secara alamiah dalam situasi normal yang tidak dimanipulasi keadaan dan kondisinya menekankan pada deskripsi secara alami. Pengambilan data atau penjaringan fenomena dilakukan dari keadaan yang sewajarnya. Oleh karena itu, peneliti terlihat langsung dilapangan. ${ }^{33}$ Adapun karakter penelitian kualitatif itu sendiri adalah sebagai berikut : a) Latar alamiah, yaitu kontek alam atau universal holistik. b) Manusia sebagai alat penelitian itu sendiri.

Sumber Data, data primer penelitian ini bersumber dari objek penelitian, dalam hal ini yang peneliti jadikan informan pada penelitian adalah: Kepala sekolah, 2 orang guru yang memberikan informasi yang dibutuhkan oleh peneliti. Sedangkan data sekunder yaitu sumber dari selain hasil wawancara atau interview, misalnya yang berasal dari dokumen-dokumen publikasi, suratmenyurat, arsip, dan lain-lain.

Teknik pengumpulan data menggunakan: observasi (Pengamatan), interview (wawancara), metode dokumenter. Teknik analisis data dalam melakukan analisis data harus disesuaikan dengan pendekatan dan desain penelitian. ${ }^{34}$ Data yang dimaksud berasal dari naskah wawancara, catatan lapangan, foto, dokumen, catatan atau dokumen resmi lainnya. Agar memperoleh hasil yang valid dan dapat dipertanggung jawabkan serta dipercaya oleh semua pihak, maka dalam penelitian ini peneliti menggunakan pengecekan keabsahan triangulasi. Untuk itu triangulasi peneliti gunakan untuk memperoleh keabsahan data mengenai berbagai problematika pelaksanaan mutu Pendidikan Agama Islam Pendidikan.

\section{Hasil dan Pembahasan}

MI. Al Hikmah Wringinanom didirikan di atas area tanah milik sendiri (wakaf untuk gedung MI) dan gedung milik sendiri (milik yayasan Al Hikmah). Letak lokasi yang cukup strategis karena berada di tengah-tengah perumahan penduduk, tepatnya di jalan Garuda 01 Dusun Simpar RT. 06 RW. 01 Wringinanom Poncokusumo Kabupaten Malang. Dengan adanya lembaga ini diharapkan warga desa dapat meningkatkan sumber daya manusia yang bermutu, beriman dan bertaqwa. sampai saat ini tetap dipercaya bahwa pendidikan formal adalah wahana utama untuk mengembangkan SDM anak didik yang dilakukan secara sistematis, pragmatis, dan berjenjang. Dalam konteks inilah pendidikan formal akan semakin dituntut peranannya dalam pembangunan manusia Indonesia yang berkualitas.

33 Suharsini Arikunto, Prosedur Penelitian: Suatu Pendekatan Praktek (Jakarta: Rineka Cipta, 2002 ), 12.

${ }^{34}$ Arikunto, 244. 
Pada mulanya warga dusun Simpar Wringinanom Poncokusumo yang cenderung agamis menyekolahkan putra-putri mereka di desa Wonorejo ditempuh dengan jalan kaki dan harus melewati sungai Amprong yang pada waktu itu masih harus menyeberang dan belum ada jembatan meski sederhana. Dalam keadaan demikian,. Maka dalam musyawarah itu disepakati untuk membentuk dan mendirikan suatu lembaga pendidikan Dari forum musyawarah yang tertanggal 21 Mei 1982 itu menghasilkan beberapa kesepakatan, yaitu: Dengan semangat kebersamaan, pada awal bulan Juli 1982 dimulailah pembangunan gedung madrasah ibtidaiyah MI ini diberi nama MI. Al Hikmah. Pada tanggal 10 Maret 2001 dibangun enam kelas dengan biaya dari swadaya.

\section{Problematika Pelaksanaan PAI di MI Al-Hikmah}

\section{a. Problem Peserta Didik}

Pendidik (guru) dan anak didik adalah dua sosok manusia yang tidak dapat dipisahkan dari dunia pendidikan. Dimana ada guru, disitu pasti ada anak didik yang ingin belajar dari guru tersebut. Begitu pun sebaliknya, dimana ada anak didik disitu pasti ada seorang guru yang ingin memberikan binaan dan bimbingan kepada anak didik. Di sekolah anak didik akan berusaha aktif mengembangkan potensi minat dan bakat yang dimilikinya dengan didukung peranan aktif para pendidik di kelas dan peserta didik dapat juga mengembangkan potensinya melalui kegiatan ekstrakurikuler yang diselenggarakan di sekolah.

Keadaan siswa di MI. Al hikmah berjumlah 113 orang. Berdasarkan hasil wawancara penulis dengan bapak Aswihani S.Pdi selaku kepala Sekolah dan ibu Masfufah selaku guru MI Al Hikmah, bahwa dalam pelaksanaan pendidikan agama Islam di MI Al Hikmah, ditemukan beberapa problem berkaitan dengan peserta didik sebagaimana berikut:

1) Rendahnya tingkat perekonomian sebagian besar wali murid. ada salah satu dari tidak dapat melanjutkan;

2) Tingkat kecerdasan yang berbeda antar siswa didik;

3) Perbedaan latar belakang keluarga dan lingkungan akan menimbulkan berbeda pula terhadap karakter anak didik.

\section{b. Problem Pendidik}

Dalam pelaksanaan pendidikan Agama Islam di Madrasah Ibtidaiyah Al Hikmah, ditemukan beberapa problem berkaitan dengan para pendidik sebagaimana berikut:

1) Gaji yang rendah berdampak kurangnya tanggung jawab dan motivasi pendidik

2) Pendidik sering mengeluh terhadap akhlak peserta didik

3) Masih ada pendidik yang belum menempuh sarjana. 
4) Perbedaan peserta didik baik dari IQ yang tinggi maupun yang rendah dan juga perbedaan karakter, maupun background kehidupan mereka. 35

\section{c. Problem Kurikulum}

Kurikulum yang dipakai di MI Al Hikmah saat ini adalah kurikulum 2013 walaupun pelaksanaannya masih sangat sederhana, kurikulum ini adalah pembenahan dari kurikulum sebelumnya. Kurikulum 2013 dikembangkan dengan memperhatikan keragaman karakteristik peserta didik, kondisi daerah, dan jenjang serta jenis pendidikan tanpa memperhatikan agama, suku, budaya \& adat istiadat serta status sosial dan ekonomi. Kurikulum meliputi substansi komponen, muatan wajib kurikulum, dan pengembangan diri secara terpadu.

Pada satuan pendidikan dituangkan dalam kompetensi yang harus dikuasai oleh peserta didik sesuai dengan beban belajar yang tercantum dalam struktur kurikulum. Kurikulum 2013 dilaksanakan melalui pendekatan tematik, kecuali untuk Pendidikan Agama Islam yang ada di madrasah tetap menggunakan pendekatan mata pelajaran yang meliputi Aqidah, Akhlak, Fiqih, Alqur'an Hadits dan Sejarah Kebudayan Islam (SKI). ${ }^{36}$

1) Dasar Pemikiran.

Kurikulum adalah seperangkat rencana dan pengaturan mengenai tujuan, isi dan bahan pelajaran serta cara yang digunakan sebagai pedoman penyelenggaraan kegiatan pembelajaran untuk mencapai tujuan pendidikan tertentu. Kurikulum 2013 ini disusun untuk memungkinkan penyesuaian program pendidikan dengan berbagai karakteristik madrasah dalam mengembangkan potensi peserta didiknya secara optimal serta memiliki kesiapan memasuki tuntutan masyarakat global.

Dewasa ini, kompetisi pendidikan berlangsung sangat ketat dan tajam hampir tiada batas. Madrasah yang tidak mampu bersaing secara fair dan terbuka akan tumbang terseleksi oleh keadaan. Oleh karena itu MI Al Hikmah Wringinanom Poncokusumo perlu mengembangkan dan meningkatkan secara terus menerus kurikulumnya dengan memperhatikan sumberdaya yang dimiliki baik sumber daya manusia maupun sumber daya lainnya.

Kondisi MI Al Hikmah Tahun Pelajaran 2018 - 2019 memiliki siswa sebanyak 113, guru sebanyak 10 orang dan pegawai administrasi sebanyak 1 (satu) orang, dukungan dan kepercayaan pemangku kepentingan (stockholders) yang tinggi, sarana dan prasarana yang

35 Wawancara Dengan Pak Asnawi Selaku Kepala Sekolah Pada 15 Septe,Ber 2019 Wawancara Dengan Ibu Masfufah Guru Pada 10 September 2019

36 Wawancara Dengan Ibu Masfufah Guru Pada 10 September 2019 
relatif mendukung, serta potensi dan kekhasan kabupaten Malang yang berada di lingkungan masyarakat pertanian, masyarakat religius, dan memiliki tingkat kesadaran pendidikan yang tinggi.

Menghadapi kondisi tersebut MI Al Hikmah Wringinanom perlu mempersiapkan diri secara mantap dengan membuat Rencana Kerja Madrasah (RKM) untuk menghadapi masa yang akan datang dan mengembangkan kurikulum 2013 sebagai kelanjutan dari uji coba KBK tahun 2004 yang memiliki karakteristik atau penekanan fokus pada upaya memenuhi kebutuhan masyarakat religius dan meningkatkan kesadaran pendidikan yang masih rendah.

Keberhasilan penyelenggaraan pendidikan di MI Al Hikmah dinyatakan tercapai apabila kegiatan belajar mampu membentuk pola tingkah laku peserta didik sesuai dengan tujuan pendidikan, serta dapat dievaluasi melalui pengukuran dengan menggunakan tes dan non tes. Proses pembelajaran akan efektif apabila dilakukan melalui persiapan yang cukup dan terencana dengan baik agar dapat diterima untuk: (1) memenuhi kebutuhan masyarakat setempat dan masyarakat global; (2) mempersiapkan peserta didik dalam menghadapi perkembangan dunia global; dan (3) melanjutkan ke jenjang yang lebih tinggi dan atau mengembangkan keterampilan untuk hidup mandiri.

Untuk menjamin keberhasilan implementasi kurikulum madrasah ini, dibutuhkan berbagai persyaratan, antara lain:

a) Dukungan semua pemangku kepentingan pendidikan (stakeholders)

b) Sosialisasi, pelatihan, diskusi dan lokakarya kurikulum 2013

c) Pemenuhan dokumen yang diperlukan untuk penyusunan kurikulum 2013

d) Pengembangan sumber daya manusia secara berkelanjutan

e) Koordinasi dan pengelolaan yang profesional

f) Perluasan kerjasama yang baik dengan berbagai pihak, seperti Perguruan Tinggi, LSM, instansi pemerintah maupun swasta, dan lain-lain.

g) Semua pihak perlu: (1) memahami kurikulum 2013; (2) memiliki dokumen pendukung; (3) memiliki komitmen untuk berkembang dan maju secara bersama-sama; serta (4) mampu dan mau melaksanakannya dengan baik.

2) Landasan

a) Undang-Undang Republik Indonesia Nomor 20 Tahun 2003 tentang Sistem Pendidikan Nasional Pasal 38 Ayat 2 , Pasal 51 Ayat 1

b) Peraturan Pemerintah RI Nomor 19 Tahun 2005 tentangStandar Nasional Pendidikan, Pasal 17 Ayat 2 dan Pasal 49 Ayat 1

c) Peraturan Menteri Pendidikan Nasional Nomor 22 tahun 2006 tentang Standar Isi 
d) Peraturan Menteri Pendidikan Nasional Nomor 23 Tahun 2006 tentang Standar Kompetensi Lulusan

e) Peraturan Menteri Pendidikan Nasional Nomor 24 Tahun 2006 tentang pelaksanaan Peraturan Menteri Pendidikan Nasional Nomor 22 dan 23 Tahun 2006

f) Surat Edaran Dirjen Pendidikan Islam Nomor: DJ.II.1/PP.00/ED/681/2006 tanggal 1 Agustus 2006, Tentang Pelaksanaan Standar Isi;

g) Pedoman Penyusunan kurikulum 2013 Kanwil Depag Jatim

h) Rencana Kerja MI Al HikmahTahun 2019 s.d 2020.37

Selanjutnya dalam pelaksanaan Pendidikan Agama Islam di Madrasah Ibtidaiyah Al Hikmah, ditemukan beberapa problem berkaitan dengan penerapan kurikulum sesuai dengan hasil wawancara penulis dengan kepala sekolah sebagai berikut :

a) Minimnya pendidik di Madrasah Ibtidaiyah Al Hikmah memahami tentang kurikulum 2013 serta penerapannya.

b) Para pendidik juga ada yang tidak membuat Rencana Pembelajaran

c) Kurikulum pemerintah yang selalu berganti-ganti dalam waktu yang cepat

\section{d. Problem Manajemen}

Fungsi manajemen pada prinsipnya dimulai dari proses perencanaan, pengorganisasian, pengarahan, pemantauan, dan penilaian atau evaluasi terhadap semua program kerja lembaga dengan pengaturan yang baik oleh para profesional untuk mengeliminasi pemborosan, (efisien) dan memaksimalkan sumberdaya yang tersedia meningkatkan pencapaian (keefektifan). Dalam pelaksanaan pendidikan Agama Islam di Madrasah Ibtidaiyah Al Hikmah, ditemukan beberapa problem berkaitan dengan manajemen dalam pendidikan Agama Islam sebagaimana dituturkan oleh Bapak Aswihani adalah berikut:

1) Kurang terjalinnya hubungan kerjasama yang baik dan harmonis antara sebagian kecil orang tua dengan pendidik sehingga segala aktifitas peserta didik yang seharusnya dikerjakan di rumah itu dikerjakan di sekolah.

2) Sedikitnya peserta didik yang berminat terhadap kegiatan keagamaan sehingga menyebabkan sulitnya wakil kurikulum menentukan bentuk kegiatan yang diminati peserta didik seperti pondok pesantren kilat.

\section{e. Problem Sarana dan Prasarana}

Prasarana pendidikan adalah semua perangkat kelengkapan dasar yang secara tidak langsung menunjang proses pendidikan di sekolah.. Sedangkan menurut keputusan menteri P dan

${ }^{37}$ Dokumentasi Buku Rentra Mi Al Hikmh 2007-2022 
K No.079/1975, sarana pendidikan terdiri dari 3 kelompok besar yaitu:a) Bangunan dan perabot sekolah.b) Alat pelajaran yang terdiri dari pembukuan dan alat-alat peraga dan labolatarium.c) Media pendidikan yang dapat dikelompokan menjadi audio visual yang menggunakan alat penampil dan media yang tidak menggunakan alat penampil.

Untuk tercapainya tujuan pendidikan tersebut, maka diperlukan kebutuhan sarana dan prasarana yang memadai dengan baik, kurang terpenuhinya sarana dan prasarana yang memadai akan dapat menghambat kelancaran proses belajar dan mengajar sebuah lembaga pendidikan, hal ini juga berlaku di Madrasah Ibtidaiyah Al Hikmah.

Dalam satu lembaga sarana dan prasarana merupakan alat penunjang keberhasilan dalam mencapai tujuan. Apalagi suatu lembaga sekolah khususnya Madrasah Ibtidaiyah Al Hikmah, sarana dan prasarana merupakan alat penunjang keberhasilan proses belajar mengajar di sekolah

Kelengkapan sarana maupun prasarana sangat menunjang bagi proses belajar mengajar. Jika dalam belajar, peserta didik menggunakan peralatan yang memadai maka kemungkinan besar belajarnya akan berhasil dengan baik. Dan sebaliknya jika peserta didik belajar dengan peralatan yang serba kurang maka kemungkinan besar akan menghasilkan berhasilnya sangat minim.

1) Masih minimnya sarana maupun prasarana

2) Lokasi pendidikan kurang kondusif dalam proses belajar mengajar sehingga ada sebagian dari pendidik yang mengajar terganggu oleh kebisingan keramaian oleh penduduk sekitarnya.

3) Kurang luasnya lahan sekolah dikarenakan tidak ada halaman.

4) Tidak memiliki ruang perpustakaan menyebabkan minimnya pengetahuan peserta didik tentang wawasan baik bersifat agama maupun bersifat umum.

5) Kurangnya perangkat/ alat-alat laboratorium pengajar sehingga menyebabkan sulitnya pengajar untuk menerapkan implementasi materi dalam mendukung kurikulum berbasis kompetensi. ${ }^{38}$

\section{Upaya Mengatasi Problematika Pelaksanaan Pendidikan Agama Islam di MI Al Hikmah}

Problematika pelaksanaan pendidikan agama Islam disekolah dapat diupayakan beberapa solusi yang diharapkan mampu menyelesaikan permasalahan yang dihadapi. Untuk mengatasi berbagai problem Pendidikan Agama Islam sebagaimana diuraikan di atas, maka madrasah melakukan berbagai upaya sebagai berikut:

38 Wawancara Dengan Ibu Masfufah 17 September 2019 


\section{a. Upaya mengatasi Problem Peserta Didik}

Solusi terhadap problem yang terdapat pada peserta didik sangat dipengaruhi oleh kesiapan individu sebagai subjek yang melakukan kegiatan belajar baik siap dalam kondisi fisik atau psikis (jasmani atau mental) individu yang memungkinkan dapat melakukan belajar.

Berdasarkan hasil wawancara penulis dengan Ibu Masfufah selaku guru di MI Al Hikmah tentang upaya yang dilakukan untuk mengatasi problem peserta didik dalam pendidikan Agama Islam yang ada di MI Al Hikmah adalah sebagai berikut: ${ }^{39}$

1) Para pendidik telah memberikan sanksi-sanksi yang bersifat mendidik bagi tiap peserta didik yang menyalahi aturan sekolah.

2) Para pendidik sudah membentuk kerja kelompok peserta didik yang diharapkan peserta didik yang mampu dapat membantu peserta didik yang tidak mampu, sehingga peserta didik yang tidak mampu dapat memahami dan mengikuti kegiatan proses belajar secara terus menerus.

3) Para Pendidik akan membentuk diskusi antar peserta didik di dalam kelas, sehingga peserta didik dapat mudah mengerti dan termotivasi untuk belajar dengan lebih baik lagi.

4) Pihak sekolah sudah mengadakan jam tambahan bagi peserta didik yang dinilai kurang mampu dalam menerima pelajaran di kelas, sehingga mereka dapat mengejar ketertinggalan mereka di kelas.

\section{b. Upaya Mengatasi Problem Pendidik}

Pendidik adalah orang dewasa yang bertanggung jawab memberi bimbingan atau bantuan kepada anak didik dalam perkembangan jasmani dan rohaninya agar mencapai kedewasaannya, mampu melaksanakan tugas sebagai makhluk Allah, Khalifah di muka bumi, sebagai makhluk sosial, dan makhluk individu yang berdiri sendiri (mandiri). 40

Sesuai hasil wawancara penulis dengan kepala sekolah mengenai upaya yang dilakukan untuk mengatasi problem pendidik dalam pendidikan Agama Islam adalah sebagai berikut:

1) Pihak Sekolah mengusahakan pada setiap pendidik untuk diikuti kegiatan pendidikan yang dapat meningkatkan wawasan dan kemampuan mereka

2) Setiap pendidik harus berusaha menggunakan berbagai metode agar mampu menciptakan suasana belajar-mengajar yang menyenangkan.

3) Setiap pendidik seyogyanya terus memahami karakter dan minat peserta didik.

39 Wawancara dengan Ibu Masfufah 17 September 2019

${ }^{40}$ Nur Uhbiyati, Dasar-Dasar Ilmu Pendidikan Islam (Semarang: PT Pustaka Rizki Putra, 2013), 65. 


\section{c. Upaya Mengatasi Problem Kurikulum}

Upaya mengatasi terhadap problem kurikulum Sesuai hasil penuturan Bapak Aswihani selaku kepala sekolah MI Al Hikmah bahwa upaya yang dilakukan untuk mengatasi problem kurikulum dalam pendidikan Agama Islam. Hasil studi bank dunia, menyimpulkan bahwa salah satu komponen pendidikan yang ikut menentukan baik-buruknya sistem pendidikan adalah kurikulum yang diberlakukan. Badan moneter dunia ini juga mensyaratkan sistem pendidikan sebuah negara dapat baik bilamana memenuhi beberapa kriteria sebagai berikut: (1)Pertama, kurikulum memenuhi sejumlah kompetensi untuk menjawab tuntutan dan tantangan arus globalisasi. (2)Kedua, kurikulum yang dibuat bersifat lentur dan adaptif dalam menghadapi perubahan yang kompetitif. (3)Ketiga, kurikulum berkorelasi dengan pembangunan sosial dan kesejahteraan masyarakat.

\section{d. Upaya Mengatasi Problem Manajemen}

Produktivitas organisasi /lembaga (Total Productivity) secara lebih luas mengidentifikasi keberhasilan dan atau kegagalan dalam menghasilkan suatu produk tertentu ( barang atau jasa ) secara kuantitas dan kualitas dengan pemanfaatan sumber-sumber dengan benar. Produktivitas bertalian dengan pelaksanaan tugs-tugas dengan cara terbaik. Produktivitas merupakan kriteria, pencapaian kerja yang diterapkan kepada individu, kelompok, organisasi atau lembaga pendidikan.

Untuk selanjutnya tentang upaya yang dilakukan untuk mengatasi problem manajemen dalam pendidikan Agama Islam di MI Al Hikmah sebagaimana yang dituturkan oleh Bapak Aswihani adalah sebagai berikut: "Terjalinya sekolah dengan masyarakat bertujuan memelihara kelangsungan hidup sekolah dan memperoleh bantuan dan dukungan dari masyarakat dalam rangka mengembangkan pelaksanaan program program sekolah." 41

\section{e. Upaya Mengatasi Problem Sarana dan Prasarana}

Sarana pendidikan sangat menunjang dalam proses belajar mengajar, hal ini akan menunjang tercapainya tujuan pembelajaran Pendidikan Agama Islam di madrasah.diantaranya adalah: Gedung sekolah yang memadai, Sekolah harus memiliki perpustakaan, Adanya alat alat peraga yang lengkap akan sangat membantu pencapaian tujuan pendidikan. sarana untuk ibadah. Kemudian upaya yang dilakukan untuk mengatasi problem sarana dan prasarana dalam pendidikan Agama Islam di MI Al Hikmah sebagaimana yang dituturkan oleh Bapak Aswihani dan Ibu Masfufah adalah sebagai berikut:

${ }^{41}$ Sudarwan Danim, Agenda Sistem Pembaharuan Pendidikan (Yogyakarta: Pusaka Belajar, 2003), 197. 
1) Pihak sekolah akan mengupayakan untuk mewujudkan sarana dan prasarana dengan menarik pada murid yang sudah lulus atau dengan mengajukan proposal permohonan bantuan kepada pihak pemerintah yang terkait dengan pendidikan.

2) Berusaha melengkapi alat dan media pembelajaran yang dapat membantu kelancaran proses belajar mengajar sehingga tujuan pembelajaran akan tercapai.

\section{E. Kesimpulan}

Hasil penelitian mendapati bahwa dalam pelaksanaan pendidikan agama Islam di MI Al Hikmah terdapat beberapa problem yaitu: (a) Pada peserta didik yakni rendahnya tingkat perekonomian, dan beberapa ber-IQ rendah. (b) Dari Pendidik: komitmen, kualitas dan kompetensi perlu ditingkatkan (c) Pada kurikulum: Minimnya pemahaman tentang kurikulum 2013 dan adanya sebagian pendidik yang tidak membuat RPP. (d) Pada manajemen: kurang terjalinnya kerjasama antara orang tua dengan pendidik. (e) Keterbatasan Sarana dan prasarana.

Upaya mengatasi problematika pelaksanaan Pendidikan Agama Islam di Madrasah Ibtidaiyah Al Hikmah dapat dilakukan dengan beberapa cara sebagaimana tersebut berikut: (a) memberikan sanksi sanksi yang bersifat mendidik bagi tiap peserta didik, mengupayakan mengadakan jam tambahan bagi peserta didik yang dinilai kurang mampu. (b) pada pendidik meliputi :dengan biaya dari lembaga setiap pendidik akan diusahakan untuk diikutsertakan dalam acara seminar, workshop. (c) pihak sekolah akan mengupayakan kepada para pendidik membuat RPP, (d) menerapkan manajemen kompetensi berbasis sekolah, meliputi menerapkan berbasis kompetensi kurikulum (e) mewujudkan sarana \& prasarana yang belum ada (perpustakaan).

Hasil penelitian berimplikasi pada para pendidik agar lebih memahami segi kelemahan dan kelebihan dari kecerdasan peserta didik dan seorang pendidik seharusnya juga memahami tentang karakter, bakat dan minat peserta didik. Bagi kepala sekolah, hasil penelitian dapat dijadikan dasar pembuatan kebijakan terkait sosialisasi penerapan tentang kurikulum yang baru secara lebih intensif kepada para pendidik yang masih belum mengerti dan juga menekankan para pendidik untuk membuat Rencana Pembelajaran agar tercapai tujuan instruksional khusus tersebut tercapai secara optimal. Hasil penelitian mengenai problematika pelaksanaan pendidikan agama Islam dalam meningkatkan mutu pendidikan ini bukan merupakan final.

\section{Daftar Rujukan}

Ahmadi, Abu, dan Nur Uhbiyati. Ilmu Pendidikan. Jakarta: Rineka Cipta, 2003.

Anwar, Moh Khoiril. "Dialog Antar Umat Beragama di Indonesia: Perspektif A. Mukti Ali." Jurnal Dakwah 19, no. 1 (2018): 89-107.

Arikunto, Suharsini. Prosedur Penelitian: Suatu Pendekatan Praktek. Jakarta: Rineka Cipta, 2002. 
Azis, Rosmiaty. "Implementasi pengembangan kurikulum." Jurnal Inspiratif Pendidikan 7, no. 1 (2018): 44-50.

Danim, Sudarwan. Agenda Sistem Pembaharuan Pendidikan. Yogyakarta: Pusaka Belajar, 2003.

Fathoni, Makmur Haris. Pendidikan Islam dan Krisis Moralisme Masyarakat Modern. Yogyakarta: IRCiSoD, 2008.

Furchan, Arief. Transformasi pendidikan Islam di Indonesia: anatomi keberadaan madrasah dan PTAI. Yogyakarta: Gama Media, 2004.

Hujair, Sanaki. Paradigma pendidikan Islam; membangun masyarakat madani. Yogyakarta: Safarina Insani Prees, 2003.

Ihsan, Hamdani, dan Fuad Ihsan. Filsafat Pendidikan Islam. Bandung: Pustaka Setia, 1998.

Indonesia, Presiden Republik. Undang-Undang Republik Indonesia Nomor 20 Tahun 2003 Tentang Sistem Pendidikan Nasional. Jakarta, 2003.

Muhaimin. Arah Baru Pengembangan Pendidikan Islam: Pemberdayaan, Pengembangan, Kurikulum hingga Redefinisi Islamiah Pengetahuan. Bandung: Nuansa Cendekia, 2003.

Muhaimin, Suti'ah, dan Nur Ali. Paradigma Pendidikan Islam: Upaya Mengefektifkan Pendidikan Agama Islam di Sekolah. 5 ed. Bandung: PT Remaja Rosdakarya, 2012.

Mulyasa, Endang. Manajemen Berbasis Sekolah Konsep Strategi dan Implikasi. Bandung: PT. Remaja Rosdakarya, 2012.

Nata, Abuddin. Paradigma pendidikan Islam. Jakarta: Gramedia Widiasarana Indonesia bekerjasama dengan IAIN Syarif Hidayatullah, 2001.

Ramayulis. Ilmu Pendidikan Islam. Jakarta: Kalam Mulia, t.t.

RM, Gagne. "The Condition of Learning and Theory of Intructions." Orlando: Rineheart and Winston, 1985.

Setianingsih, Deny. "Pemikiran Pendidikan Islam Muhammad Tholhah Hasan.” Universitas Negeri Islam Maulana Malik Ibrahim, 2008.

Soetrisno, Eddy. Kamus Populer Bahasa Indonesia. Ladang Pustaka, 2008.

Surya, Djumhur Muhammad. Bimbingan dan Penyuluhan di Sekolah Jilid 3. Bandung: Erlangga, 2003.

Suyanto, dan Djihad Hisyam. Refleksi dan reformasi pendidikan di Indonesia memasuki Milenium III. Jakarta: Adicita, 2000.

Tafsir, Ahmad. Ilmu pendidikan dalam perspektif Islam. Bandung: Remaja Rosdakarya, 1994.

Uhbiyati, Nur. Dasar-Dasar Ilmu Pendidikan Islam. Semarang: PT Pustaka Rizki Putra, 2013.

Yunus, Mahmud. “Metodik Khusus Pendidikan Agama.” Jakarta: Hidakarya Agung, 1983. 